\title{
Routine of the unpredictable: workloads and health of urgent and emergency nursing workers
}

\author{
Rotina do imprevisivel: cargas de trabalho e saúde de trabalhadores \\ de enfermagem de urgência e emergência \\ Rutina de lo imprevisible: cargas de trabajo y salud para los \\ trabajadores de enfermeira de emergência
}

\section{How to cite this article: Mass SFLS, Centenaro, APFC, Santos $A F$, Andrade A, Franco GP, Cosentino SF. Routine of the unpredictable: workloads and health of urgent and emergency nursing workers. Rev Gaúcha Enferm. 2022;43:e20210007. doi: https://doi. org/10.1590/1983-1447.2022.20210007}

a Pesquisadora autônoma. Palmeira das Missōes, Rio Grande do Sul, Brasil.

Universidade Federal de Santa Maria Campus Palmeira das Missōes (UFSM-PM), Departamento de Ciências da Saúde, Laboratório de Estudos em Saúde, Enfermagem e Trabalho. Palmeira das Missões, Rio Grande do Sul, Brasil.

-Hospital de Clínicas de Passo Fundo (HCPF). Programa de Residência Multiprofissional en Urgência e Emergência/Intensivismo. Passo Fundo, Rio Grande do Sul, Brasil.

Pesquisadora autônoma. Santa Maria, Rio Grand do Sul, Brasil.

\section{Suéllen Fortes de Lima Santos Mass ${ }^{\mathrm{a}}$ Alexa Pupiara Flores Coelho Centenarob Arlíni Fátima dos Santos ${ }^{c}$ Andressa de Andrade ${ }^{b}$ Gianfábio Pimentel Franco ${ }^{b}$ Susane Flôres Cosentino ${ }^{d}$}

\section{ABSTRACT}

Objective: To know the perceptions of nursing professionals in urgent and emergency services regarding workloads and the relationship with their health.

Method: Descriptive qualitative study carried out in two urgent and emergency sectors in southern Brazil. 16 nursing professionals were interviewed. The data were subjected to thematic content analysis.

Results: The first thematic category highlighted the workloads in the daily lives of professionals, highlighting Covid-19 as an element recently incorporated into the perception of biological load. The psychic load is enhanced by stress and suffering in the face of deaths, in addition to adverse working conditions. The second category showed the interface between the loads, the overload and the workers health, highlighting the importance of the psychic load in mental health.

Conclusion: Workloads are enhanced by working conditions and the relationship with the profession's work object, generating overload and risk of mental illness.

Keywords: Nursing. Occupational health. Emergency medical services.

\section{RESUMO}

Objetivo: Conhecer as percepções dos profissionais de enfermagem de serviços de urgência e emergência quanto às cargas de trabalho e a relação com sua saúde.

Método: Estudo qualitativo descritivo realizado em dois setores de urgência e emergência do Sul do Brasil. Foram entrevistados 16 profissionais de enfermagem. Os dados foram submetidos à análise temática de conteúdo.

Resultados: A primeira categoria temática evidenciou as cargas de trabalho no cotidiano dos profissionais, destacando Covid-19 como elemento recentemente incorporado à percepção da carga biológica. A carga psíquica é potencializada pelo estresse e sofrimento frente aos óbitos, além das condições laborais adversas. A segunda categoria evidenciou a interface entre as cargas, a sobrecarga e a saúde dos trabalhadores, destacando a importância da carga psíquica na saúde mental.

Conclusão: As cargas de trabalho são potencializadas pelas condições laborais e pela relação com o objeto de trabalho da profissão, gerando sobrecarga e risco de adoecimento psíquico.

Palavras-chave: Enfermagem. Saúde do trabalhador. Serviços médicos de emergência.

\section{RESUMEN}

Objetivo: Conocer las cargas de trabajo percibidas por los profesionales de enfermería en los servicios de urgencias y emergencias y su relación con su salud.

Método: Estudio descriptivo cualitativo realizado en dos sectores de urgencias y emergencias del sur de Brasil. Se entrevistó a 16 profesionales de enfermería. Los datos se sometieron a análisis de contenido temático.

Resultados: La primera categoría temática destacó las cargas de trabajo en el día a día de los profesionales, destacando el Covid-19 como un elemento recientemente incorporado a la percepción de carga biológica. La carga psíquica se vio reforzada por el estrés y el sufrimiento ante las muertes, además de las condiciones laborales adversas. La segunda categoría mostró la interfaz entre las cargas, la sobrecarga y la salud de los trabajadores, destacando la importancia de la carga psíquica en la salud mental.

Conclusión: Las cargas de trabajo se ven potenciadas por las condiciones laborales y la relación con el objeto de trabajo de la profesión, generando sobrecarga y riesgo de enfermedad mental.

Palabras clave: Enfermería. Salud laboral. Servicios médicos de urgencia. 


\section{口INTRODUCTION}

Urgent and emergency services are complex and dynamic environments ${ }^{(1)}$. Ideally, work in these sectors is engaging, motivating and challenging, capable of providing growth and professional excellence for the nursing worker. However, in the daily lives of these professionals, coexist contemporary barriers and challenges faced daily in the routine of health care in these units ${ }^{(2)}$.

In urgent and emergency services, there is a set of demands and responsibilities placed on nursing professionals, who often need to manage them in the context of critical situations that require immediate decision-making. There are psychological stressors in the daily lives of these professionals, which include the management of serious or potentially serious patients, overcrowding of services, adverse working conditions, violence and few resources to meet the demand, which culminates in occupational stress. As a result of these elements, despite the pleasure and identification with work, nursing professionals do not always stand to remain in these sectors ${ }^{(3)}$.

Studies have shown a set of vulnerabilities of nursing professionals working in these units. Workers deal with patients at imminent risk of death on a daily basis ${ }^{(3,4)}$. There is work overload and living with a toxic environment, in which nursing often experiences physical, mental and emotional exhaustion related to work $^{(3)}$. Thus, the nursing workers in this scenario presents as a population to which studies that identify their perception of the workloads present in the work environment need to be directed.

Workloads are elements present in the work process that translate the relationship between work and the worker wear process. They are dynamic elements that interact with each other and with the worker's body, generating a need for adaptation, resistance and enhancing its effects on the health-disease process of those who work ${ }^{(5)}$. They are inherent elements of the work process and environment that are closely related to the worker's health ${ }^{(6)}$.

This study assumes the classification of workloads according to their internal or external materiality. The internal materiality loads are psychic (represented by the elements that cause psychic wear) and physiological (result of the different ways of mobilizing the body to perform tasks and translated into physical effort, need for displacement and body positioning)(5,7).

The external materiality loads are the physical loads (derived from the technical demands of the work and intensified by physical elements of the environment); chemical loads (derived from the object of work and auxiliary materials for its transformation, including chemical substances, dust, smoke, gases and liquids); the mechanical loads (derived from work technology, from the operation of machines and equipment, from the objects that make up the environment and also from the conditions of installation and maintenance of the means of production); and the biological ones (derived from the object of work and from the environmental hygiene conditions, which include animal or plant microorganisms that can cause damage to the worker's health) ${ }^{(5,7)}$.

Studying the workloads of urgent and emergency nursing professionals can contribute to the understanding of how these workers perceive the nature of their work, how they adapt (or not) to it, and whether there is a perception of the impact on their health. The importance of research on this theme is justified, as nursing makes up an important part of the health workforce and its engagement is determinant for the results obtained in the care of seriously or potentially severe patients in urgent and emergency services.

With this in view, the present study was based on the following research question: How do urgent and emergency services nursing workers perceive workloads and the relationship with their health? From this, this study aimed to know the perceptions of nursing professionals in urgent and emergency services regarding workloads and the relationship with their health.

\section{METHOD}

This is a descriptive qualitative research. The study scenarios were composed by two sectors: the urgent and emergency unit of a philanthropic hospital and the Mobile Emergency Care Service (Serviço de Atendimento Móvel de Urgência - SAMU), both located in a city in the countryside of Rio Grande do Sul, Brazil.

The study participants were the nursing professionals working in these places. The nursing team totaled 22 workers (nurses and nursing technicians). Two professionals working for less than six months and one professional who was on maternity leave during the period of data production were excluded. Therefore, 19 professionals were approached at their workplace and invited to participate in the study. From these, 16 accepted and composed the sample of this research.

Data were obtained through individual semi-structured interviews, in June and July 2020. After a pilot interview, a script was created by the research team for the matrix project that addressed: the perceptions and feelings of professionals in their workspace; perception about external and internal elements that interfered with their body, mind and work; perception of the relationship of these elements with their health. The interview also included the survey of socio-occupational data to characterize the participants: gender; age; 
race; professional training; work shift; professional training time; and time of performance in urgency and emergency.

Interviews were performed at the workplace or outside, as requested by each participant. All meetings were conducted by the research team, in private places that guaranteed safety and comfort to those involved.

The meetings began with the presentation of the research project and reading of the Free and Informed Consent Form, ending with the signing of the form in duplicate and clarification of all doubts and ethical issues. From this, a socio-occupational questionnaire was filled out, containing variables related to: gender, age, race, academic training (nurse or nursing technician) and work shift. Afterwards, the in-depth interview itself was conducted, using a semi-structured script. This stage lasted an average of 20 minutes.

Audio recordings of the semi-structured interviews and full transcription in the Microsoft Word 2010 text editor were performed. Data transcriptions made up the corpus of analysis. Data were subjected to thematic content analysis, which was developed in three phases: pre-analysis; exploration of the material; and data processing and interpretation ${ }^{(8)}$.

Pre-analysis comprises the first stage of data organization. The researcher begins to organize the material so that it becomes useful for the research. At this phase, the ideas are systematized by performing a fluctuating and exhaustive reading, which implies initially knowing the material and creating familiarity with it ${ }^{(8)}$. At this moment, the research team focused on the intellectual appropriation of the research material, choosing the elements that contributed to the objective of the study, and reserving the empirical material that composed the secondary database.

When completing the exploration of the material, the researcher must proceed to the definition of categories, classifying the constitutive elements of a set characterized by differentiation and performing the regrouping by analogy, through criteria previously defined ${ }^{(8)}$. This phase was carried out with the support of the Microsoft Word 2010 text editor, using the chromatic analysis technique.

Each statement was separated by affinity of meaning and colors were assigned for their separation and better identification of similarities. This movement facilitated the classification of registration units comprising comparable words, sentences, paragraphs and with the same semantic content as a given textual content. Six registration units were extracted from the material under analysis: workloads, work overload, risk of aggression, risk of accidents, work and health interface.

Finally, for the interpretation and processing of the data obtained through this research, in property of the thematic categories, in order to answer the study question, national and international articles were read in order to identify similarities or distances in relation to the findings in the study, strengthening the discussion, thus making inferences and interpretations of the results.

This research complied with the ethical and legal precepts established by Resolution No. 466/12 and 510/16 of the National Health Council. In the presentation of the results, the deponents were identified by the letter P, for "professional", followed by the cardinal number representing the order the interview and the designation of the unit to which they are assigned: ER (referring to Emergency Room) or SAMU. This study was approved by the local Research Ethics Committee, under Certificate of Presentation for Ethical Consideration No. 27545620.9.0000.5346 and Protocol No. 3.800.078.

\section{RESULTS}

The participants in this research had an average age of 39 years. The youngest was 23 years old and the oldest 57 years old. From the 16 interviewees, nine were male and seven were female. Regarding race, ten self-declared white and six brown.

Regarding training, nine participants were nursing technicians and seven were nurses. In relation to work shifts, 12 were assigned to the mixed shift, two to the afternoon shift and two to the night shift.

Regarding the training time, there was an approximate average of 13 years, with the professional who had been working the shortest time in the profession had graduated for one year and five months, and the one who had been working the longest had 27 years since graduation. As for the time of work in the urgent and emergency area, there was an average of six years of work. The professional who worked the longest had 11 years in the specialty and the one who worked the least time, one year and four months. And of these, seven professionals had specialization in the area.

The categories listed are presented below:

\section{In the routine of the unpredictable: the loads in the daily work in urgency and emergency}

The statements of the professionals interviewed in this study evidenced that nursing work in urgent and emergency care involves components such as pressure and the unpredictability of demands for a typical work shift. The routine of the unpredictable is evidenced as a characteristic dynamic of these services:

My work doesn't have a routine [...] every day is different [...] You never know exactly whatyou're going to find [...] 
You arrive at a scene, you created a scenario in your head and many times when you arrive, it's completely different [...] you are often exposed to situations for which you don't have total control, despite having training (P1 - SAMU).

[...] we don't know what will happen. [...] You may be able to rest, just as you may not be able to. You can eat like you can't eat. You can go to the bathroom, just as you cannot go to the bathroom (P12 - ER).
The unpredictable is intersected by workloads, whether those of external materiality (physical, chemical, mechanical, and biological loads) or those of internal materiality (physiological and psychic). Chart 1 shows the set of workloads reported by urgent and emergency nursing professionals:

It is worth noting that the psychic load, which corresponds to a load of internal materiality, was the referred element most emphasized by the professionals. Working with urgency

\begin{tabular}{|c|c|c|}
\hline Workloads & Emerging themes & Statements \\
\hline Physical & Climate elements & $\begin{array}{l}\text { [...] Weather adversity [...] is a difficulty [...] the excess of rain, cold } \\
\text { (P13 - SAMU). }\end{array}$ \\
\hline \multirow{2}{*}{ Mechanical } & \multirow{2}{*}{ Lack of PPE and hard technologies } & $\begin{array}{l}\text { [...] Lack of PPE and hard technologies [...] lack of medication, } \\
\text { the respirator doesn't work at the right time, it's stressful in this } \\
\text { part (P9-ER). }\end{array}$ \\
\hline & & $\begin{array}{l}\text { [...] sometimes, I prefer to go to an appointment and not wear } \\
\text { glasses [...] because it starts to fog up, you waste time, some } \\
\text { PPE, their adjustment is not correct (P13-SAMU). }\end{array}$ \\
\hline \multirow{2}{*}{ Biological } & \multirow{2}{*}{ Covid-19 sanitary crisis } & $\begin{array}{l}\text { [...] every time a Covid transport call comes in it's agonizing, } \\
\text { you have to dress, expose yourself to the risk of contamination } \\
\text { (P1 -SAMU). }\end{array}$ \\
\hline & & $\begin{array}{l}\text { [...] now we are in this pandemic, there are small children at } \\
\text { home, there are families at risk as well, father and mother with } \\
\text { diabetes (P10-SAMU). }\end{array}$ \\
\hline Chemical & \multicolumn{2}{|c|}{ It was not evidenced in the statements. } \\
\hline \multirow[t]{2}{*}{ Physiological } & $\begin{array}{l}\text { Ergonomic and } \\
\text { postural requirements }\end{array}$ & $\begin{array}{l}\text { [...] spine, because in the service, one thing you don't take care is } \\
\text { this issue of squatting, of correct position [...] you have to carry } \\
\text { the patients for a distance, leave the back of a courtyard, for } \\
\text { an alley, taking to the ambulance, going down the stairs with } \\
\text { a wheelchair, so this compromises the issue of joints a lot (P1 } \\
\text { - SAMU). }\end{array}$ \\
\hline & $\begin{array}{l}\text { Interference in eating patterns and } \\
\text { the sleep-wake cycle }\end{array}$ & $\begin{array}{l}\text { [...] eating is out of the routine, sleep, you have to sleep during } \\
\text { the day because at night you can't sleep, because you provide } \\
\text { care [...]so this physical fatigue is a routine (P4 - SAMU). }\end{array}$ \\
\hline Psychic & Work stress & $\begin{array}{l}\text { [...] Our service is often against time, it causes a lot of stress. } \\
\text { Sometimes you arrive from a care service, you can't sleep, you } \\
\text { can't rest, it's so strong it's adrenaline [...] (P1 - SAMU) }\end{array}$ \\
\hline
\end{tabular}

Chart 1 - Workloads reported by urgent and emergency nursing workers based on emerging themes from the analysis and statements. Palmeira das Missões, RS, Brazil, 2020 Source: research database. 
and emergency involves a set of intense feelings, such as for example, in the daily care of critically ill patients or facing death, especially when the victim is a child, as illustrated in the statements:

\section{[...] / already caught an accident once it was with a fam- ily and two children, I had just become a mother, that disturbed a lot, we only took the little boy alive, we were massaging this little boy to the hospital, so these are things that spoil my day, I closed my eyes and remem- bered (P3-SAMU) \\ [...] The part of going together to share this news to the family [death] and holding the ends was very difficult, I stayed for months and months... We already sleep little because we have a different routine, I was more than months without sleep, I was very debilitated (P9 - ER).}

\section{Interface between loads, overload and the health of urgent and emergency nursing workers}

Urgent and emergency nursing professionals mentioned the effect of workloads on their work dynamics and on their lives. The workloads - in particular, the psychic load - promote experiences of wear and overload. Whether due to the unpredictable routine or the importance of their performance in highly complex situations, nursing professionals from both services reported feeling overloaded, as can be seen in the statements:

[...] We feel with a responsibility beyond what would be our purview. We often feel apprehensive for being at risk of making the wrong decision (P5 - SAMU).

[...] The routine is tiring, you often don't have time to take a break. It's pretty busy. Sometimes it's midnight and you haven't even been able to drink water. When you think you will be able to sit down, drink water and liftyour legs a little, two or three patients arrive (P9 - ER).

$[. .$.$] There is the issue of responsibility as well, it demands$ a lot from you, both for the team coordination and for the responsibility with the patient, with the family, so it is a tiring work [...] (P11 - ER).

The professionals mentioned the interference of work overload in their private lives, highlighting the difficulty in reconciling work and family:
[...] Sometimes my wife asks: "Aren't you going out today? You will stay at home?". Sometimes it's all you want, sometimes there are shifts when you arrive so exhausted, so tired, that you want to watch cartoons with your son on television (P1 - SAMU).

[...] the routine makes you tired, every day, there is no weekend, there is no holiday, you cannot plan to travel. [...] I don't have a child and I don't intend to have it because of that, because I'm going to have to drop something [...] (P4 - SAMU).

Finally, when asked about the interface of workloads and work overload in their health and in their lives, professionals from both sectors mentioned the risks and damages related to the profession, expressed above all by work accidents and even experiencing situations of violence in their daily lives:

[...] Many times you are exposed to biological risks, explosion, an accident itself. You are on a public road, you are often exposed to being hit by car, collision, all these factors (P1 - SAMU).

[...] The professionals / saw most suffering work accidents are the emergency, both with exposure to biological material, via percutaneous, ocular, mucosal (P11 - ER).

[...] Even aggression happens [...] You have to register against the person, call the police [...] Last shift we suffered practically an attempt there, with the patient very debilitated, who arrived ill, almost dying and the family member on the outside with more than ten people threatening: "If he die, we'll go in, we'll break everything, we'll make it do it and happen" (P9 - ER).

In the set of risks and damages that are reinforced by loads and work overload, professionals from both sectors highlighted the psychological damage and damage to their mental health:

[...] / think it interferes a lot with mental health. I'm here with you now, we could be telling a joke, and in seconds we go [to the service], you arrive in an accident that looks like a horror movie scene [...] (P8 - SAMU).

[...] I go home and I can't forget. So I think it affects my mental health. Sometimes I'm charged at home, but I can't leave the hospital and pretend that nothing happened, I wasn't stressed, I wasn't bothered or I didn't suffer from anything. Mental health is the most affected (P11 - ER). 


\section{DISCUSSION}

The results of the first thematic category indicate, firstly, the understanding that nursing work in urgent and emergency care is complex and dynamic. A study of the review of the international literature on nursing work in urgent and emergency care confirmed that the nature of this work is based on the unpredictable. Professionals often compare their daily lives to a "trench", in which there is a constant state of alert due to elements that cannot always be predicted or controlled ${ }^{(3)}$. Without the certainty of what a typical work shift will look like, professionals assume the routine of the unpredictable as a characteristic of their work.

Nursing professionals working in urgent and emergency sectors provide critical care in dynamic, high-risk and highstress environments ${ }^{(1,4)}$. These professionals are at the frontline of health care, which places them in a routine of high demands and responsibility ${ }^{(4)}$. Therefore, the unpredictable is a reflection of the complexity of their work object, which cannot be predicted and is conditioned to the demand of the community.

As a result, urgent and emergency work is challenging and has elements that enhance the workloads for nursing professionals. In this regard, the deponents listed a set of elements that, in their perception, increased these charges. These elements, for the most part, are in line with similar research that investigated the perception of nursing professionals from different sectors about these loads ${ }^{(9-13)}$.

However, some particularities regarding the workloads of this study should be discussed. One of them refers to the biological load. Health professionals did not mention exposure to biological material (such as blood and other secretions), fungi and bacteria, which is different from other recent research ${ }^{(0,12,13)}$. But they cited the health crisis caused by Sars-CoV-2, which is a reflection of the pandemic moment in which the data were produced.

Urgent and emergency sectors are considered to be at high risk for infection by Sars-CoV-2, causer of Covid-19. These sectors are usually the gateway for patients with respiratory symptoms into the public health system, before they are tested or identified as to the stage of infection ${ }^{(14)}$. Nursing professionals in these sectors are, therefore, at the frontline of fighting the pandemic, which is reflected in their perception of the biological workload.

It was also observed that professionals did not identify elements related to chemical charges. This may be related to the low perception of the effects of chemical agents on their body (such as contact with medications, solutions, gases, vapors, aerosols and particles). Authors suggest that the elements involved in workloads are not always clearly perceived by professionals ${ }^{(15)}$. Perhaps the pandemic moment caused by Covid-19, mentioned above, was concentrating the attention of nursing professionals on loads other than chemical.

It should be noted, however, that psychic loads were more emphatically present in the participants' statements. This is in line with investigations that evidenced psychic workloads as the main responsible for the exhaustion of nursing professionals, culminating in damage to their health and well-being, such as insomnia and anxiety ${ }^{(9,12)}$.

The care service for critically ill pediatric patient, as well as family management in the context of the death of a family member, were the situations highlighted by the professionals and related to the increase in the psychic load at work. A study showed that the experience with the child in serious situations and working with families are elements that worsen the psychic load in nursing work ${ }^{(12)}$, which is in line with the results.

The second thematic category shows how workloads culminate in professional wear processes and harm their health. This is in line with research that evidenced a statistically significant association between the intensity of workloads perceived by nursing professionals and their perception of wear ${ }^{(16)}$.

The intensification of workloads contributes to the precariousness of work. Chemical, physical, biological, organic, ergonomic and psychic elements, combined or separately, increase the efforts made by workers and contribute to their wear process. In response to this, (over)workloads trigger impacts on the professional's body and mind, which can cause illness ${ }^{(6)}$.

Urgent and emergency nursing professionals mentioned the constant feeling of responsibility on their work associated with psychic overload. It is known that there is strong pressure on urgent and emergency nursing workers. They are expected to respond to different situations with ability and confidence, without margin for errors, in contexts where immediate actions play a decisive role in clinical outcomes ${ }^{(4)}$.

It is understood that urgent and emergency nursing professionals are responsible for a set of behaviors from the initial assessment, care management and safety of severe or potentially severe patients ${ }^{(17)}$. This pressure on the worker can culminate in an increase in the psychic load and, consequently, in overload. In line with this, qualitative research carried out with nurses showed that psychic workloads were enhanced by the feeling of responsibility in making important decisions. Added to this, demands on the part of the head and the multidisciplinary team, as well as the daily pressure in different work situations, increased the psychic load and, consequently, culminated in overload ${ }^{(10)}$. 
It is important to recover the nature of work in urgency and emergency, in which nursing professionals need to manage their responsibilities in critical situations. However, the high load that work imposes on them can influence their decision-making and, in the long term, promote their exhaustion ${ }^{(18)}$. Therefore, despite recognizing that there are workloads inherent to the nature of work, it should be considered that adverse conditions often enhance them.

The literature has shown that the elements that most intensely enhance workloads are linked to precariousness and deficits in the work environment, materials and equipment, in addition to the excess demand for care services ${ }^{(11,15)}$. This corroborates the data described in the first and second thematic categories, revealing that working conditions and daily demand are key elements in the increase in workloads and work overload.

Scientific evidence indicates that psychosocial risks in the work of nursing professionals are related to different stressors in their daily lives, such as intense workload and high levels of responsibility. These elements tend to increase stress and promote psychosocial damage ${ }^{(10,13)}$. In line with this, the statements show that the interference of overload in the personal and family life of these individuals, which suggests the existence of psychosocial damage.

Other risks and damages related to workloads and overload were mentioned by the nursing professionals, which mainly included the risks of illness, accidents and violence at work, results that are similar to those of other studies ${ }^{(11,13,15)}$. This reinforces the component of high occupational risk that characterizes urgent and emergency services, whose health professionals incur in work accidents at high rates when compared to other populations of workers in general ${ }^{(19)}$.

Violence suffered by users was also evidenced in another research, in which nursing professionals considered conflicts with users as the main element that enhances workloads. Violence, demands and pressure for care are exhausting and wearing events for professionals ${ }^{(11)}$.

An Australian cross-sectional study carried out with urgent and emergency nursing professionals showed that $87 \%$ of the participants reported having suffered some episode of violence at work in the six months prior to the research. The authors argue that violence at work, despite being potentially harmful to the health and integrity of these professionals, is often trivialized as part of nursing work ${ }^{(20)}$.

Finally, the deponents evidenced the interface of workloads and work overload in their mental health. It is known that the increase in workloads can cause dissatisfaction, wear and, in some cases, illness among nursing professionals ${ }^{(15)}$. The organization and precariousness of working conditions are involved in this process of psychic burden. The high work demand, the inherent rigor of daily activities, violence and, at times, the absence of sick colleagues are elements capable of promoting psychic illness among nursing workers ${ }^{(11)}$.

It should be understood that perhaps there will always be, in nursing work, elements that will increase workloads. These are conditions inherent to the insertion of the worker in adverse situations. The translation of this suffering into illness will depend on the subjectivity of each individual, their coping strategies and resilience ${ }^{(11)}$. However, it is important that there is investment in improving the organization and working conditions, so that workloads are alleviated and illness at work mitigated $(9,11,12)$.

Furthermore, it is also suggested that there be an institutional and social movement of recognition and valorization of the nursing work. The importance of the category's workforce as the central axis of health care must receive visibility and a sensitive and attentive look by the institutions. Strategies for achieving this objective can be: strengthening the autonomy of nurses in decision-making processes; institutional support of nursing in different everyday situations; proper dimensioning of human resources and improvements in working conditions; strengthening of actions for mental health promotion at work, prioritizing spaces for welcoming and listening to professionals.

It is known that listening, valuing the reality of workers and the creation of dialogic and participatory spaces are powerful tools to provide professionals with reflections on their workloads and to find measures to reduce their effects ${ }^{(6)}$. Therefore, it is suggested that the workers themselves, based on their experience, can mobilize to strengthen the nursing work, based on institutional actions that allow them space, opportunity, and autonomy.

\section{FINAL CONSIDERATIONS}

The results of this study showed that urgent and emergency nursing professionals are inserted in a dynamic and challenging daily work, in which the routine of the unpredictable is revealed as a remarkable characteristic of these sectors. The workloads of internal and external materiality were evidenced in the professionals'statements, highlighting the Covid-19 health crisis as an element recently incorporated into the perception of the biological load.

The psychic load was highlighted by the professionals, enhanced by elements such as stress and suffering in the face of deaths, in addition to the adverse conditions of care service. The increase in workloads translated into the perception of work overload and impacts on the mental health of professionals. At the end of the study, it can be concluded that the nursing workloads in urgent and emergency care 
are enhanced by elements present in daily care related to working conditions and the relationship with the profession's work object, which culminates in overload and risk of psychic illness.

Regarding the limitations of the study, it can be considered the temporality of data collection, as the participants' perception of workloads is related to the specific period in which the data were produced. However, it is considered that these findings are important in terms of management of urgent and emergency services, which have the challenge of developing actions aimed at promoting health at work and mitigating factors that cause illness.

The results of this study can be applied: in management, offering subsidies for actions to promote health and well-being at work; in extension, through partnerships between teaching and service to carry out participatory actions with workers; in teaching, so that reflections on the relationship between health and work to be part of nursing education. It is suggested that further research be conducted with urgent and emergency nursing professionals, applying experimental methodological designs that are capable of measuring the impact of the actions suggested in this study on the health and working conditions of nursing professionals.

\section{DEFERENCES}

1. Schneider A, Weigl M. Associations between psychosocial work factors and provider mental well-being in emergency departments: a systematic review. PLoS One. 2018;13(6):e0197375. doi: http://doi.org/10.1371/journal. pone. 01797375.

2. Castner J. Professional flourishing: the job demands-resources model and emergency nursing. J Emerg Nurs. 2019;45(6):607-10. doi: http://doi. org/10.1016/j.jen.2019.09.008

3. GormanVL. Future Emergency nursing workforce: what the evidence is telling us. J Emerg Nurs. 2019;45(2):132-6. doi: http://doi.org/10.1016/j.jen.2018.09.009.

4. Schumaker J, TaylorW, McGonigleT. The emergency, trauma, and transport nursing workforce: highlights of a benchmark 2019 survey. Nurs Manage. 2019;50(12):2032. doi: http://doi.org/10.1097/01.NUMA.0000605152.42445.4b.

5. Laurell AC, Noriega M. Processo de produção e saúde: trabalho e desgaste operário. São Paulo: Hucitec; 1989

6. Coelho APF, Beck CLC, Silva RM, Vedootto D0, Prestes FC. Workload of recyclable material collectors: a proposal for nursing care. Rev Gaúcha Enferm. 2018:39:e20180006. doi: https://doi.org/10.1590/1983-1447.2018.2018-0006.
7. Laurell AC. A saúde-doença como processo social. In: Nunes ED, organizador. Medicina social: aspectos históricos e teóricos. São Paulo: Global; 1983.

8. Bardin L. Análise de conteúdo. 8. ed. Santo André: Geográfica Editora; 2011.

9. Mendes M, Trindade LL, Pires DEP, Biff D, Martins MMFPS, Vendruscolo C. Workloads in the family health strategy: interfaces with the exhaustion of nursing professionals. Rev Esc Enferm USP. 2020;54:e03622. doi: https://doi. org/10.1590/s1980-220x2019005003622.

10. Biondi HS, Pinho EC, Kirchhof ALC, Rocha LP, Barlem ELD, Kerber NPC. Psychic workload in the process of work of maternity and obstetric centers nurses. Rev Gaúcha Enferm. 2018;39:e64573. doi: https://doi.org/10.1590/1983-1447.2018.64573.

11. Scherer MDA, Oliveira NA, Pires DEP, Trindade LL, Gonçalves ASR, Vieira M. Aumento das cargas de trabalho em técnicos de enfermagem na atenção primária à saúde no Brasil. Trab Educ Saúde. 2016;14(1 Supl.):89-104. doi: https://doi. org/10.1590/1981-7746-sol00030.

12. Michaello RS, Tomaschewski-Barlem JG, Carvalho DP, Rocha LP, Bordignon SS, Neutzling BRS. Perception of nursing workers about the workloads in a neonatal intensive care unit. Rev Fun Care Online. 2020;12:54-61. doi: http:// doi.org/10.9789/2175-5361.rpcfo.v12.6983.

13. Walton AL, Rogers B. Workplace hazards faced by nursing assistants in the United States: a focused literature review. Int J Environ Res Public Health. 2017;14(5):544. doi: https://doi.org/10.3390/ijerph14050544.

14. Song X, Fu W, Liu X, Luo Z, Wang R, Zhou N, et al. Mental health status of medical staff in emergency departments during the coronavirus disease 2019 epidemic in China. Brain Behav Immun. 2020;88:60-5. doi: https://doi.org/10.1016/j. bbi.2020.06.002.

15. Biff D, Pires DEP, Forte ECN, Trindade LL, Machado RR, Amadigi FR, et al. Nurses' workload: lights and shadows in the family health strategy. Ciênc Saúde Coletiva. 2020;25(1):147-58. doi: http://doi.org/10.1590/1413-81232020251.28622019.

16. Carvalho DP, Rocha LP, Pinho EC, Tomaschewski-Barlem JG, Barlem ELD, Goulart LS. Workloads and burnout of nursing workers. Rev Bras Enferm. 2019;72(6):1435-41. doi: https://doi.org/10.1590/0034-7167-2017-0659.

17. Curtis K, Munroe B, Van C, ElphickTL. The implementation and usability of HIRAID, a structured approach to emergency nursing assessment. Australas Emerg Care. 2020;23(1):62-70. doi: https://doi.org/10.1016/j.auec.2019.10.001.

18. Rubio-Navarro A, Garcia-Capilla DJ, Torralba-Madrid MJ, Rutty J. Ethical, legal and professional accountability in emergency nursing practice: an ethnographic observational study. Int Emerg Nurs. 2019;46:100777. doi: https://doi. org/10.1016/j.ienj.2019.05.003.

19. Reichard AA, Marsh SM, TonozziTR, Konda S, Gormley MA. Occupational injuries and exposures among emergen cy medical services workers. Prehosp Emerg Care. 2017;21(4):420-31. doi: http://doi.org/10.1080/10903127.2016.1274350.

20. Pich JV, Kable A, Hazelton M. Antecedents and precipitants of patient-related violence in the emergency department: results from the australian VENT study (Violence in Emergency Nursing and Triage). Australas Emerg Nurs J. 2017;20(3):107-113. doi: http://doi.org/10.1016/j.aenj.2017.05.005. 


\section{- Funding:}

This study was carried out with resources from the Research Incentive Fund (Fundo de Incentivo à Pesquisa

- FIPE) of the Universidade Federal de Santa Maria

(UFSM).

\section{- Authorship contribution:}

Conceptualization - Suéllen Fortes de Lima Santos

Mass, Alexa Pupiara Flores Coelho Centenaro.

Data curation - Alexa Pupiara Flores Coelho Centenaro.

Formal analysis - Suéllen Fortes de Lima Santos Mass,

Arlíni Fátima dos Santos.

Funding acquisition - Alexa Pupiara Flores Coelho

Centenaro.

Investigation - Suéllen Fortes de Lima Santos Mass,

Arlíni Fátima dos Santos.

Methodology - Suéllen Fortes de Lima Santos Mass,

Arlíni Fátima dos Santos.

Project administration - Suéllen Fortes de Lima Santos

Mass, Alexa Pupiara Flores Coelho Centenaro, Arlíni

Fátima dos Santos.

Resources - Alexa Pupiara Flores Coelho Centenaro.

Supervision - Alexa Pupiara Flores Coelho Centenaro.

Validation - Andressa de Andrade, Gianfábio Pimentel

Franco, Susane Flôres Cosentino.

Visualization - Andressa de Andrade, Gianfábio

Pimentel Franco, Susane Flôres Cosentino.

Writing-original draft - Suéllen Fortes de Lima Santos

Mass, Arlíni Fátima dos Santos.

Writing-review \& editing - Suéllen Fortes de Lima

Santos Mass, Alexa Pupiara Flores Coelho Centenaro,

Andressa de Andrade, Gianfábio Pimentel Franco,

Susane Flôres Cosentino.

The authors declare that there is no conflict of interest.

\section{- Corresponding author:}

Alexa Pupiara Flores Coelho Centenaro.

E-mail: alexa.coelho@ufsm.br

\section{Associate editor:}

Cecília Helena Glanzner 